\title{
Analisis Pelaksanaan Ekstrakurikuler Pramuka Terhadap Nilai-nilai Karakter Siswa di SD Negeri Pamongan 2
}

\author{
Irma Ristantina Luthviyani \\ Universitas PGRI Semarang \\ irmaristhvi97@gmail.com
}

Eka Sari Setianingsih

Universitas PGRI Semarang

ekasari129@yahoo.com

\section{Diana Endah Handayani}

Universitas PGRI Semarang

handayani.hitam@gmail.com

\begin{abstract}
Extracurricular Scouts are external educators who use among systems to guide and familiarize themselves with each Scout member having character. Activities are considered as complementary activities of the process of learning activities in schools. The values contained in scouting are very helpful in the process of instilling character to children. The age of elementary school children is very appropriate to lay the foundation for formation of the concept morality and foster character values in it. The purpose of this study was to analyze the process of conducting scout extracurricular activities towards the character values of students in Pamongan Elementary School 2. The research method used a deskritive qualitative approach, the instrument of this research was students and character values in the Scouts. Data collection techniques use, questionnaires, interviews, observation and documentation. The data analysis technique uses data collection, reducing data, presenting data and drawing conclusions. The results of study activities which contain character values and have a positive impact and done through habituation obedience figures. The system among and program activities of students is arranged systematically directed. So, it can be concluded that Scout extracurricular activities are carried out through habituation on an ongoing basis.
\end{abstract}

Keywords: Extracurricular, Scouting, Character Values

\begin{abstract}
Abstrak
Pramuka ekstrakurikuler adalah pendidik eksternal yang menggunakan sistem untuk membimbing dan membiasakan diri dengan setiap anggota Pramuka memiliki karakter. Kegiatan dianggap sebagai kegiatan pelengkap dari proses kegiatan belajar di sekolah. Nilai-nilai yang terkandung dalam kepramukaan sangat membantu dalam proses
\end{abstract}


menanamkan karakter kepada anak-anak. Usia anak sekolah dasar sangat tepat untuk meletakkan fondasi bagi pembentukan konsep moralitas dan menumbuhkan nilai karakter di dalamnya. Tujuan dari penelitian ini adalah untuk menganalisis proses pelaksanaan kegiatan scout ekstrakurikuler terhadap nilai-nilai karakter siswa di Sekolah Dasar Pamongan 2. Metode penelitian menggunakan pendekatan kualitatif deskriptif, instrumen penelitian ini adalah siswa dan nilainilai karakter di Pramuka. Teknik pengumpulan data menggunakan, kuesioner, wawancara, observasi dan dokumentasi. Teknik analisis data menggunakan pengumpulan data, reduksi data, penyajian data, dan penarikan kesimpulan. Hasil kegiatan belajar yang mengandung nilainilai karakter dan memiliki dampak positif dan dilakukan melalui angka-angka kepatuhan pembiasaan. Sistem antara kegiatan program dan siswa diatur secara sistematis diarahkan. Jadi, dapat disimpulkan bahwa kegiatan ekstrakurikuler Kepanduan dilakukan melalui pembiasaan secara berkelanjutan.

Kata kunci: Ekstrakurikuler, Kepramukaan, Nilai Karakter

\section{Pendahuluan}

Pramuka singkatan dari Praja Muda Karana. Pramuka berdasarkan Kamus Besar Bahasa Indonesia (2007: 892) adalah organisasi untuk pemuda yang mendidik para anggotanya di berbagai keterampilan, disiplin, kepercayaan pada diri sendiri, saling menolong, dan sebagainya. Ekstrakulikuler Pramuka dianggap sebagai kegiatan pelengkap dari proses kegiatan belajar di sekolah. Menurut Tope dalam Permendikbud Nomor 63 Tahun 2014 tentang pendidikan kepramukaan sebagai ekstrakurikuler wajib, bahwa: "Kurikulum 2013 pendidikan kepramukaan ditetapkan sebagai kegiatan ekstrakurikuler wajib. Hal ini mengandung makna bahwa pendidikan kepramukaan merupakan kegiatan ekstrakurikuler yang secara sistemik diperankan sebagai wahana penguatan psikologis-sosial-kultural (reinfocement) perwujudan sikap dan keterampilan kurikulum 2013 yang secara psikopedagogis koheren dengan pengembangan sikap dan kecakapan dalam pendidikan kepramukaan. Dengan demikian pencapaian Kompetensi Inti Sikap Spiritual (KI-1), Sikap Sosial (KI-2), dan Keterampilan (KI-3) memperoleh penguatan bermakna (meaningfull learning) melalui fasilitasi sistemik-adaptif pendidikan kepramukaan di lingkungan satuan pendidikan."

Terlebih, pada era sekarang para pemuda dan pemudi karakternya menurun sehingga perlu adanya pembiasaan dan pendidikan untuk merubah sikap. Menurut Azzef (2014: 27) pendidikan karakter adalah pendidikan budi pekerti plus, yaitu yang melibatkan aspek pengetahuan (cognitive),perasaan (feeling), dan tindakan (action). Karakter sangat penting dan sebagai bekal dalam mengarungi kehidupan baik dalam kolaborasi, komunikasi, tata atur bahasa dan perilaku yang mencerminkan sebagai warga negara yang baik. Perlu adanya dorongan penuh untuk mengembangkan potensi siswa yang dimiliki dan mewujudkan karakter yang baik perindividunya. Namun, ditengah era globalisasi ini Pramuka mampu menyatukan perbedaan. Pramuka tidak mengenal tua maupun muda semua setara, sama-sama mencari ilmu, pengetahuan, pengalaman dan saling belajar. Learning by doing merupakan salah satu fondasi yang kuat dalam menggerak karakter bangsa khususnya anak muda saat ini. Pengaruh pelaksanaan ekstrakurikuler Pramuka terhadap nilai-nilai karakter diperkuat dengan jurnal artikel dari Aji, A.H. (2016:8293) melaporkan bahwa kiasan Dasar, kegiatan ekstrakurikuler Pramuka digunakan untuk memberikan pendidikan karakter siswa agar memiliki semangat perjuangan dan memiliki corak budaya yang jelas. Menurut jurnal penelitian oleh Woro dan Marzuki (2016: 68) keteladanan Pembina Pramuka dalam memberikan contoh yang 
baik berupa perilaku maupun perkataan kepada peserta didik. Hal ini dilakukan mengingat beberapa peserta didik akan lebih mudah menyerap nilai dari contoh atau model yang ditunjukkan oleh orang lain sehingga Pembina Pramuka dituntut untuk dapat memberikan contoh bagi peserta didik.

Namun, perbedaan karakteristik dalam penelitian ini adalah pembiasaan dan pola cakupan karakter dalam membina melalui kegiatan Pramuka. Peneliti lebih cenderung melihat bagaimana cara pembina menanamkan karakter siswa SD Negeri Pamongan 2 Demak tertata dan mampu dibiasakan dalam kesehariannya. perilaku siswa menunjukkan karakter tanggung jawab saat proses pelaksanaan ekstrakurikuler Pramuka dan pembelajarannya di kelas. Keteladanan Pembina Pramuka dalam memberikan contoh yang baik berupa perilaku maupun perkataan kepada siswa. Hal ini dilakukan beberapa peserta didik akan lebih mudah menyerap nilai dari contoh atau model yang ditunjukkan oleh orang lain sehingga Pembina Pramuka dituntut untuk dapat memberikan contoh bagi peserta didik.

Cakupan ekstrakulikuler Pramuka bagi kelas tinggi dan rendah di SD Negeri Pamongan 2 Demak berbeda dikarenakan adanya PRODIK (Program Kegiatan Peserta Didik). Program kegiatan tersebut tiap gugus depan terutama Sekolah Dasar ada dua golongan pramuka yaitu Siaga dan Penggalang. Untuk Pramuka Siaga berusia 7-10 tahun dengan kegiatan yang menggembirakan, dinamis, kekeluargaan dan berkarakter. Sedangkan Pramuka Penggalang berusia 11-15 tahun dikemas dengan kegiatan yang karakter, dinamis, progresif dan menantang. Sehingga dari dua golongan Pramuka menghasilkan kreativitas yang berbeda namun memiliki nilai-nilai karakter yang sama.

Nilai-nilai Pramuka dalam darma Pramuka telah mencakup seluruh karakter bangsa yang wajib ditanamkan kepada siswa. Menurut Hudiyono (2012: 70-82) ada nilai-nilai karakter yang bersahabat dan berkesinambungan dengan ekstrakurikuler Pramuka, adalah sebagai berikut : 1) Karakter religius, 2) Karakter jujur, 3) Karakter toleransi, 4) Karaker disiplin, 5) Karakter kerja keras, 6) Karakter kreatif, 7) Karakter mandiri, 8) Karakter demokratis, 9) Karakter rasa ingin tahu, 10) Karakter semangat kebangsaan, 11) Karakter cinta tanah air, 12) Karakter menghargai prestasi, 13) Karakter bersahabat/komunikatif, 14) Karakter cinta damai, 15) Karakter gemar membaca, 16) Karakter peduli lingkungan, 17) Karakter peduli sosial, dan 18) Karakter tanggung jawab.

Sebagai pelaksanaan terhadap fungsi dan tujuan nilai-nilai karakter tersebut, SD Negeri Pamongan 2 Demak mempunyai misi yaitu "Terwujudnya Sekolah yang Unggul, Berprestasi, Berkarakter Imtaq dan Iptek, Berbudaya, serta Cinta Tanah Air. Untuk mencapai visi tersebut, sekolah merumuskan rencana aksi/tindakan (action plan) berupa misi sekolah di antaranya yang berkaitan dengan pendidikan karakter, yakni Meningkatkan penghayatan dan pengamalan terhadap ajaran agama yang dianut sehingga terbangun insan yang beriman, bertaqwa serta berakhlaqul karimah, menumbuhkembangkan semangat berprestasi dan mewujudkan budaya kompetitif yang jujur, sportif bagi seluruh warga sekolah dalam berlomba meraih prestasi, menumbuhkembangkan semangat bersaing dalam memperoleh prestasi sampai tingkat propinsi, menyelenggarakan kegiatan pembelajaran yang berkualitas melalui pendekatan pembelajaran berpusat pada siswa (Student Centered Learning) dengan multi metode dan media, antara lain PAKEM atau Contectual Teaching Learning (CTL) berorientasi pada Broad Base Education (BBC) yang mengembangkan keterampilan, kecakapan hidup (Life Skill) dan pembelajaran scientific, menerapkan manajemen partisipasi dan transparan dengan melibatkan seluruh warga serta komite sekolah (Stakeholder) dalam pengelolaan sekolah, menumbuhkembangkan budaya tertib, disiplin, santun dalam tutur kata dan sopan dalam perilaku terhadap sesama, 
mendidik dan membimbing siswa agar memiliki kesadaran dan kepedulian terhadap kelestarian lingkungan sekitar, mendidik dan membimbing siswa agar memiliki kesadaran Cinta Tanah Air. Hal ini sejalan dengan fungsi Gerakan Pramuka dalam Kementerian Pemuda dan Olahraga Republik Indonesia, Undang-Undang Nomor 12 Tahun 2010 pada Bab II Pasal 3 tentang fungsi Gerakan Pramuka dinyatakan, pendidikan dan pe-latihan Pramuka, pengembangan Pramuka, pengabdian masyarakat dan orang tua, dan permainan yang berorientasi pada pendi-dikan. Gerakan Pramuka hadir sebagai alat untuk pembentukan karakter yang berben-tuk kegiatan pendidikan nonformal di sekolah. Gerakan Pramuka sebagai organi-sasi kepanduan yang berkecimpung dalam dunia pendidikan yang bersifat nonformal berusaha membantu pemerintah dan ma-syarakat dalam membangun bangsa dan negara. Hal ini dapat dilihat dari prinsip dasar metodik pendidikan Pramuka yang tercantum dalam Dasa Darma Pramuka, yaitu: (1) Takwa kepada Tuhan Yang Maha Esa; (2) Cinta alam dan kasih sayang sesama manusia; (3) Patriot yang sopan dan kesatria; (4) Patuh dan suka bermusyawarah; (5) Rela menolong dan tabah; (6) Rajin, terampil, dan gembira; (7) Hemat, cermat, dan bersahaja; (8) Disiplin, berani dan setia; (9) Bertanggung jawab dan dapat dipercaya; (10) Suci dalam pikiran, perkataan, dan perbuatan.

Peneliti meyakini bahwa nilai-nilai karakter yang terdapat di dalam mata pelajaran Pendidikan Kewarganegaraan seperti religius, toleransi, nasionalisme, tanggung jawab, cinta tanah air, demokratis, kerja sama dan lain-lain dapat dikembangkan dan dibentuk melalui kegiatan ekstrakurikuler Pramuka. Ralitas dilapangan bahwa siswa masih kurang dalam pembentukan dan pembiasaan penanaman nilai-nilai karakter. Hal ini dibuktikan ketika siswa menyontek pekerjaan temannya, mengabaikan tugas dari guru, membuang sampah sembarangan, upacara tidak khidmat dan lain sebagainya. Maka dari itu, menanamkan 18 nilai-nilai karakter salah satunya dapat dilakukan melalui kegiatan ekstrakurikuler Pramuka.

Berdasarkan latar belakang masalah maka, peneliti merumuskan masalah bagaimana pelaksanaan ekstrakulikuler pramuka terhadap nilai-nilai karakter siswa di SD Negeri Pamongan 2 ?.

Tujuan dalam penelitian ini adalah untuk mengetahui bagaimana proses pelaksanaan ekstrakurikuler Pramuka, proses pembiasaan karakter melalui kegiatan Pramuka dan dampak maupun hasilnya. Sehingga nantinya mendapatkan bahan informasi dan menganalisis untuk mengembangkan nilai-nilai karakter melalui ekstrakurikuler Pramuka yang berada di SD Negeri Pamongan 2.

\section{Metode}

Jenis penelitian ini adalah kualitatif deskriptif. Menurut Sugiyono (2015: 289) dalam penelitian ini adalah suatu rumusan masalah yang memandu peneliti untuk mengeksplorasi dan atau memotret situasi sosial yang akan diteliti secara menyeluruh, luas dan mendalam. Sedangkan menurut Moleong (2017:6) penelitian kualitatif adalah penelitian yang bermaksud untuk memahami fenomena tentang apa yang dialami oleh subjek penelitian misalnya perilaku, persepsi, motivasi, tindakan. Secara holistic dan dengan cara deskripsi dalam bentuk kata-kata dan bahasa, pada suatu konteks khusus yang alamiah dan dengan memanfaatkan berbagai metode alamiah.

Penelitian dilaksanakan kurang lebih selama 2 bulan, yaitu terhitung dari bulan Mei sampai dengan bulan Juni 2019. Penelitian ini dilaksanakan di SD Negeri Pamongan 2, Kabupaten Demak. Subjek penelitian ini adalah Pembina Pramuka SD Negeri Pamongan 2, siswa kelas III, IV dan V yang mengikuti ekstrakurikuler pramuka. Sekolah SD Negeri Pamongan 2 menggunakan kurikulum 2013. Alasan 
memilih sekolah tersebut karena sebelumnya telah melakukan need assesment yang terjadi di luar jam pelajaran. Kemudian diperkuat dengan kepala sekolah dan guru kelas tentang pembiasaan keseharian di kelas dan lingkungan dalam pelajaran sekolah.

Pengumpulan data dimulai dengan penentuan sampel penelitian dan subjeknya. Sebelum memulai wawancara, peneliti menciptakan hubungan saling percaya kepada pihak yang dituju. Kemudian peneliti memperkenalkan diri maksud dan tujuan dalam melakukan penelitian. Setelah setuju pihak yang dituju dalam pelaksanaan penelitian yang dilakukan oleh peneliti maka diberikan surat kesediaan partispasi, membahas tentang waktu dan tempat dalam proses pengumpulan data baik angket, wawancara, observasi maupun dokumentasi sebagai penunjang informasi.

Peneliti melakukan penganalisa data yang dimulai dengan observasi di dalam kelas dan saat kegiatan Pramuka berlangsung. Setelah itu melakukan wawancara peneliti menggunakan wawancara tidak terstruktur dengan kepala sekolah, guru kelas, pembina Pramuka Siaga dan Penggalang serta siswa kelas III-V yang mengikuti ekstrakurikuler Pramuka. Dilakukan adanya angket yang bersifat terbuka dan tertutup dan diisi oleh pembina dan siswa. Tahapan terakhir adalah dokumentasi yang memperkuat informasi sumber yang diperoleh secara rinci.

Berdasarkan sumber data yang digunakan ini ada dua jenis data, yaitu data primer dan data sekunder. Data primer adalah berbagai informasi dan keterangan yang diperoleh langsung dari sumbernya, yaitu para pihak yang dijadikan sumber informasi atau subjek yang telah ditentukan oleh peneliti. Data sumber ini lebih fokus tentang kegiatan Pramuka dan penanaman nilai-nilai karakter. Sedangkan data sekunder adalah informasi dari berbagai buku yang berisi teori-teori yang mengenai Pramuka dan penanaman karakter, serta berbagai dokumen yang mendukung.

Adapun instrumen yang digunakan dalam penelitian ini adalah pedoman observasi, pedoman wawancara, pedoman angket dan pedoman dokumentasi. Setelah itu tahapan analisis data dilakukan saat memasuki lapangan penelitian berlangsung. Keterbatasan peneliti yang telah dilakukan adalah waktu penelitian mendekati bulan Ramadhan sehingga menyesuaikan jadwal yang telah disusun oleh pembina serta berdiskusi alur proses pengambilan data tentang kegiatan Pramuka saat berlangsung serta membutuhkan waktu yang lama untuk mengamati sikap siswa.

\section{Hasil}

a. Temuan Penelitian

Temuan hasil penelitian ini terdapat perbedaan karakteristik siswa saat mengikuti ekstrakurikuler Pramuka di SD Negeri Pamongan 2 Demak yaitu berpikir kritis dan mengatur strategi dalam merancang suatu masalah dengan cepat. Ini terbukti ketika siswa berlatih lomba dengan sungguh-sungguh serta kejuaraan yang diraih, merancang kegiatan dan mengatur strategi dibantu pembina Pramuka untuk mendapatkan kejuaraan tiap perlombaan. Pembina Pramuka berasal dari guru SD Negeri Pamongan 2 Demak. Pembina selalu mengajarkan materi yang harmonis dan kekeluargaan. Hal ini beda dari SD yang lain karena menuntut untuk menyelesaikan SKU (Syarat Kecakapan Umum) secara terburu-buru dan membuat siswa menjadi takut namun pembina di SD Negeri Pamongan 2 Demak tidak terburu-buru untuk menyelesaikannya namun lebih membina dengan kekeluargaan dan saling sharing bagaimana cara menyelesaikannya, aura kewibawaan, ketegasaan dan kceriaan harus terpancarkan ketika saat membina agar siswa merasa senang serta nyaman saat 
dibina sehingga menimbulkan antusias. Hal ini juga terbukti $90 \%$ siswa sangat minat mengikuti ekstrakurikuler Pramuka bahwa berpengaruh perannya dalam pembentukan nilai-nilai karakter siswa. SD Negeri Pamongan 2 Demak merupakan sekolah umum bukan sekolah islam namun dalam keaatan beribadah adalah nomor satu, setiap waktu jam untuk beribadah maka semua aktivitas diberhentikan sejenak untuk shalat berjamaah. Bagi yang non islam tetap di kelas dan membawa kitab sesuai agama masing-masing. Maka dari itu, nilai agama di SD Negeri Pamongan 2 Demak ditanamkan sejak dini agar siswa memahami bahwa agama merupakan fondasi hidup.

b. Nilai-Nilai Karakter

Berdasarkan hasil penelitian bahwa Nilai-nilai karakter siswa berlangsung dengan baik memulai pembiasaan yang dilakukan oleh warga sekolah. Ekstrakurikuler Pramuka menerapkan bermain sambil belajar untuk memperhatikan perkembangan pola pikir siswa dalam menerima pembelajaran dari materi dan tugas yang diberikan kakak Pembina Siaga maupun Penggalang. Hal tersebut dibuktikan dengan hasil observasi ekstrakurkuler Pramuka, berikut penjelasannya, sebagai berikut:

1. Karakter religius

Karakter religius pada siswa menunjukkan sikap patuh dalam menjalankan keyakinan amanah masing-masing, toleransi sesama manusia. Contohnya melakukan ibadah shalat dhuhur secara berjamaah di mushola sekolahan, mencium tangan guru sebagai tanda hormat, selalu bersyukur atas rahmat yang diberikan Tuhan Yang Maha Esa dan akur dengan teman. Hal ini dibuktikan setiap paginya membaca alqu'an dan asmaul husna ketika belajar didalam kelas serta melaksanakan doa bersama.

2. Karakter jujur

Karakter jujur tercermin pada siswa saat mengakui kesalahan yang dilakukan, mengerjakan tugas dari pembina, mengaku saat datang terlambat dan bertanggung jawab atas pilihannya. Siswa juga menjawab jujur ketika ditanya apakah merasa nyaman atau tidak saat melakukan ekstrakurikuler Pramuka.

3. Karakter Toleransi

Karakter ini mengajarkan siswa, meskipun berbeda-beda seperti berbeda rambut, warna kulit, berbeda kelas bahkan berbeda pendapat. Pembina Pramuka memberikan permainan untuk saling kerjasama dan mengajarkan kepada siswa untuk meminimalisir adanya perbedaan.

4. Karakter Disiplin

Karakter ini timbul dari dasar kerelaan siswa dengan senang hati tanpa adanya sebuah keterpaksaaan. Pembina Pramuka melatih siswa untuk terbiasa disiplin seperti datang tepat waktu, membentuk barisan sebelum masuk ke kelas, melaksanakan tugas piket dan berpakaian rapi saat melaksanakan ekstrakurikuler Pramuka. Kegiatan tersebut terbukti saat ekstrakurikuler Pramuka berlangsung dengan tertib dan disiplin.

5. Karaker Kerja Keras

Karakter kerja keras ini dilatih Pembina Pramuka untuk menerima tantangan dari setiap tugas yang diberikan dan dikemas untuk melatih kinerja pola pikir siswa yang kreatif. Tugas yangg diberikan bisa berbentuk kelompok maupun individu. Siswa dilatih untuk siap setiap saat untuk menghadapi tantangan, baik itu latihan lomba dengan sungguh-sungguh dan belajar dengan tekun.

6. Karakter Kreatif

Karakter ini, pembina memberikan tugas kepada siswa untuk mencipakan yel-yel Pramuka tiap barong maupun regu agar nantinya bisa dikemas menarik dan menciptakan kesenangan bagi siswa. Manfaat dalam berpola 
pikir kreatif mampu membuat siswa lebih bekerja keras dan membangun mitra antar teman untuk menciptakan sesuatu hasta karya yang unik.

7. Karakter Mandiri

Karakter mandiri tercermin dari tindakan siswa yaitu mengerjakan tugas yang diberikan pembina Pramuka apabila bersifat individu, mengenakan pakaian sendiri, mengendalikan emosi, membiasakan diri kepada hal-hal kebaikan dan suka menabung. Latihan ekstrakurikuler Pramuka pada nilai karakter mandiri membawa dampak positif bagi diri siswa untuk mengatur kebutuhan yang dimiliki dan pembiasaan diri.

8. Karakter Demokratis

Karakter demokratis terlihat dari kegiatan pramuka dalam menentukan ketua kelompok dalam mengerjakan tugas kelompok dari pembina, menaati perintah yang diberikan oleh ketua barung maupun ketua regu, saling bertukar pendapat untuk menyelesaikan tugas kelompok secara diskusi dan mengutamakan kepentingan bersama daripada prbadi untuk mendapatkan mufakat dalam musyawarah.

9. Karakter Rasa Ingin Tahu

Karakter ini terlhat saat eksrakurikuler Pramuka dengan antusias siswa ingin mengetahui materi apa yang akan diajarkan dan tentunya menunggu ice breaking dalam sela-sela pembelajaran ketika membosankan. Pertanyaan-pertanyaan akan timbul ketika siswa tidak mengetahui apa yang didapatkan informasi, menyelesaikan tugas bahkan suatu permasalahan yang dirundingkan bersama pembina Pramuka. Dari karakter ini menimbulkan pembelajaran yang bermakna dan timbul balik antar manusia.

10. Karakter Semangat Kebangsaan

Karakter ini terlihat saat upacara pembukaan maupun penutupan ekstrakurikuler Pramuka berlangsung. Petugas yang ditunjuk sangat antusias, senang dan berlatih dengan sungguh-sungguh untuk menjaga amanah serta melaksanakan tugasnya dengan baik. Menyanyikan lagu kebangsaan dengan sungguh-sungguh dan memahami makna arti kiasan bendera merah putih.

11. Karakter Cinta Tanah Air

Karakter ini tercermin saat mengikuti upacara dengan tertib sebagai wujud syukur dan mengenang jasa para pahlawan yang telah gugur. Siswa juga senang dan menyukai produk bangsa sendiri seperti baju, sepatu, buku dan hasil bumi. Selain itu, tradisi kebudayaan juga disenangi oleh siswa yaitu Dugderan (acara menyambut bulan puasa),Arak-arakan (acara malam takbiran menyambu hari kemenangan saat idul fitri), Suronan (acara menyambut bulan 1 muharram) dan Karnaval (acara menyambut hari lahir Kemerdekaan Indonesia tiap tanggal 17 Agustus). Serta makanan khas Demak adalah nasi kropokan dan buah khasnya yaitu belimbing.

12. Karakter Menghargai Prestasi

Karakter ini terlihat saat ekstrakurikuler Pramuka ditunjuk sebagai perwakilan lomba jamran maupun jambore. Siswa dilatih pembina untuk bersungguh-sungguh dan memotivasi diri untuk memberikan yang terbaik. Jikapun saat perlombaan mendapatkan kemenangan memberikan ucapan selamat dan rasa syukur serta terima kasih kepada siapapun yang telah mendukung. Apabila dalam perlombaan mengalami kekalahan menerimanya dengan lapang dada, sabar dan berniat dalam diri untuk berlatih sungguh-sungguh.

13. Karakter Bersahabat/Komunikatif

Karakter ini terlihat dan tercermin saat di sekolahan maupun di masyarakat unuk berbicara menggunakan bahasa yang baik dan santun serta bersikap terbuka. Siswa apabila diberikan tugas kelompok oleh 
pembina dilakukannya melalui diskusi dengan teman sekolompok untuk mendapatkan hasil yang maksimal.

14. Karakter Cinta Damai

Karakter ini terlihat pada siswa dalam menjaga keselarasan dan keharmonisan sesama warga sekolah SD Negeri Pamongan 2 sehingga tercipta nuansa cinta damai dan kerukunan. Cinta damai diajarkan sedini mungkin oleh pembina dengan cara memberi contoh langsung kepada peserta didik untuk berani mengakui kesalahan dan meminta maaf, bertanggung jawab akan kesalahan dan rendah hati.

15. Karakter Gemar Membaca

Karakter ini terlihat ketika siswa membaca buku yang diberikan oleh pembina seperti membaca dan menghafalkan satya dan darma Pramuka dan keersediaannya perpustakaan sekolah untuk mendalami tentang wawasan serta pengetahuan.

16. Karakter Peduli Lingkungan

Karakter ini terlihat dan tercermin dalam budaya lingkungan di sekolah yaitu melaksanakan kewajiban melalui tugas piket membersihkan kelas, membersihkan selokan, membuang sampah di tempat yang telah disediakan. Pembina melatih siswa untuk menjaga dan melestarikan lingkungan sekolah seperti merawat tanaman, menjaga kebesihan diri dan mencegah wabah penyakit.

17. Karakter Peduli Sosial

Karakter ini dilatih dan diajarkan untuk membantu teman yang mengalami kesusahan maupun musibah, peduli terhadap orang lain, mengikuti kerja baki sekolahan dan ketika iuran bumbung rasa yang bertujuan memberikan dampak positif bagi siswa tentang kepedulian terhadap sesama yang lebih membutuhkan. Siswa tidak membeda-bedakan teman semua dirangkul dan mudah bergaul.

18. Karakter Tanggung Jawab

Karakter ini terliha saat latihan ekstrakurikuler Pramuka terhadap tugas dan kewajiban yang diembannya. Ketika menjadi ketua barung maupun regu untuk merangkul teman-teman aktif dalam kegiatan, menyelesaikan tugas sesuai waktu yang diinstruksikan dan menjaga amanah.

\section{Pembahasan}

Pada penelitian ini yang berjudul "Analisis Pelaksanaan Ekstrakurikuler Pramuka terhadap nilai-nilai karakter siswa di SD Negeri Pamongan 2." Adanya pengembangan ekstrakurikuler pramuka tiap pelaksanaanya dan dikemas secara menarik, sehingga memberikan konstribusi yang positif dalam dunia pendidikan seperti siswa dapat mengatur waktu secara efektif, suka bermusyawarah, taat aturan yang ada, lebih peduli sesama manusia dan lingkungan di sekitarnya. Pelaksanaan kegiatan ekstrakurikuler pramuka di SD Negeri Pamongan 2 diawali dengan kegiatan perencanaan Program yang telah disusun secara terstruktur atas pertimbangan rapat gugus depan, pelaksanaan program, pengevaluasian setiap akhir kegiatan dan melaksanakan ujian Syarat Kecakapan Umum (SKU).

Ekstrakurikuler Pramuka salah satu dampak penerapan nilai-nilai karakter siswa karena merupakan pendidikan eksternal yang kompleks, menyenangkan dan menarik sehingga tidak bosan dalam menerima pembelajaran. Menurut filsuf Yunani Heraklitus dalam Lickona (2013: 4) bahwa karakter adalah takdir. Karakter membentuk takdir dari seorang pribadi. Karakter membentuk takdir seluruh masyarakat. Hal ini dibuktikan dengan observasi penelitian yang berlangsung dengan baik dan antusias siswa dalam mengikutinya. Hasil penelitian sesuai dengan teori yaitu membangun kebiasaan, membentuk figur panutan yang dijadikan teladan 
untuk mengembangkan potensi yang dimiliki. Bahwa karakter merupakan hal penting yang harus dipupuk secara dini untuk siswa.

Kajian Penelitian Yang Relevan dari Utomo (2015), yang berjudul "Pelaksanaan Ekstrakurikuler Pramuka Di SD Negeri IV Wates". Hasil penelitiannya menunjukkan bahwa dari pihak sekolah sebenarnya memberikan beberapa faktor pendukung dalam pelaksanaan ekstrakurikuler pramuka, diantaranya adanya program, tersedia sarana prasarana, dan sekolah menyediakan dana yang berasal dari Bantuan Operasional Sekolah (BOS). Hal ini membedakan dengan bentuk penelitian yang dilakukan oleh peneliti yaitu menganalisa 18 nilai-nilai karakter yang tertuang di ekstrakurikuler Pramuka. Mengkaji perihal itu, diterapkan Kurikulum 2013 yang mewajibkan ekstrakurikuler Pramuka wajib dikalangan pendidikan dan nilai-nilai karakter didalamnya kompleks bagi karakteristik tiap indvidu terutama kalangan pemuda.

Ekstrakurikuler Pramuka menerapkan bermain sambil belajar untuk memperhatikan perkembangan pola pikir siswa dalam menerima pembelajaran dari materi dan tugas yang diberikan kakak Pembina Siaga maupun Penggalang. Manfaat ekstrakurikuler Pramuka di SD Negeri Pamongan 2 Demak memberikan dampak kepada warga sekolah khususnya siswa yaitu mengavaluasi diri untuk kearah yang lebih baik, menunjang prestasi dan mampu mengasah minat bakatnya melalui kegiatan Pramuka. Dari pengamatan maupun penilaian pembina bahwa Pramuka di SD Negeri Pamongan 2 Demak sudah baik dalam koordinasi, administrasi dan program pelatihan untuk siswa. Sehingga siswa mendapatkan pengetahuan, pengalaman dan wawasan yang luas melalui ekstrakurikuler Pramuka serta pemberian materi yang dikemas secara menarik. Pola pikir siswa menjadi kreatif dalam penuntasan tugas yang diberikan dan mengasah keterampilan siswa.

\section{Simpulan}

Berdasarkan hasil penelitian yang telah dilaksanakan dapat disimpulkan bahwa peran pembina sebagai mitra perkembangan dalam penanaman karakter melalui pramuka harus didukung penuh oleh pihak sekolah dan orangtua. Sebab hal ini merupakan salah satu faktor penting dalam mempengaruhi proses penanaman karakter tersebut. Ekstrakurikuler Pramuka mengandung nilai-nilai karakter didalamnya dan dilaksanakan dengan baik melalui pembiasaan serta adanya keteladan. Pelaksanaan ekstrakurikuler Pramuka disusun secara struktur, administrasi yang baik dan cara membina yang baik sehingga dalam penyampaian materi kepada siswa tercapai.

Dampaknya berpengaruh pada kebiasaan siswa. Pemberian contoh sikap merupakan satu bagian dari sistem among untuk menjadi figur yang mampu mengembangkan potensi yang dimiliki anggota Pramuka Siaga dan Penggalang yaitu kelas III, IV serta V. Keteladanan yang dimaksud adalah memberikan contoh sikap yang baik yang mengandung nilai-nilai karakter. Pemberian contoh sikap yang baik kepada peserta didik merupakan salah satu bagian dari sistem among. Sistem among biasa digunakan dalam pembelajaran ekstrakurikuler pramuka untuk membentuk peserta didik agar berjiwa merdeka, disiplin, dan mandiri dalam hubungan timbal balik antar manusia.

Pembiasaan dilakukan secara teratur dan berkesinambungan. Figur ketauladanan memberikan contoh agar nantnya siswa berperilaku sesuai nilai-nilai karakter secsra optimal. Pembiasaan dan keteladanan ini dilakukan sukarela tanpa adanya keterpaksaan yang nantinya diwujudkan sebagai bentuk peran dalam membentuk karakter pribadi menjadi baik. Contoh implementasinya adalah budaya antri ketika berwudhu, membeli jajan, budaya disiplin untuk datang tepat waktu, menghormati 
dan menyayangi baik muda maupun tua. Siswa selalu antusias saat ekstrakurikuler Pramuka berlangsung dan merupakan minat dalam mengembangkan potensinya.

\section{Saran}

Berdasarkan hasil penelitian yang telah dilakukan oleh peneliti, memberikan saran diantaranya:

1. Menjadi literatur untuk peneliti lainnya yang mengambil penelitian ekstrakurikuler.

2. Peneliti menyarankan agar dalam ekstrakurikuler Pramuka dilengkapi sarana dan prasaran sebagai alat media dalam menyampaikan materi latihan berlangsung.

3. Mendorong dan mendukung potensi siswa dalam mengembangkan minat bakatnya terhadap ekstrakurikuler Pramuka.

\section{Referensi}

Aji, A.H. 2016. Pendidikan Karakter Dalam Ekstrakurikuler Pramuka di SMP Negeri 1 Yogyakarta. Jurnal Kebijakan Pendidikan. 5, 82-96.

Azzef, A.M.2014.Urgensi Pendidikan Karakter Di Indonesia. Yogjakarta:AR-RUZZ Media

Hudiyono.2012.Membangun Karakter Siswa Melalui Profesionalisme Guru dan Gerakan Pramuka.Surabaya:Esensi.

Kementerian Pemuda dan Olahraga Republik Indonesia. 2011. Undang-Undang Republik Indonesia Nomor 12 Tahun 2010 Tentang Gerakan Pramuka. Jakarta

Lickona, Thomas.2013.Mendidik Untuk Membentuk Karakter, Bagaimana Sekolah Dapat Memberikan Pendidikan Tentang Sikap Hormat dan Bertanggung Jawab.Jakarta:Bumi Aksara

Moleong. 2017. Metodelogi Penelitian Kualitatif. Bandung: Rosda

Pusat Bahasa Departemen Pendidikan Nasional. 2007. Kamus Besar Bahasa Indonesia Edisi Ketiga. Jakarta: Balai Pustaka

Sugiyono. 2015. Metode Penelitian Pendidikan Pendekatan Kuantitaif, Kualitatif, dan $R \& D$. Bandung:Alfabeta.

Tope, Mustofa.Salinan Lampiran I dan II Peraturan Menteri Pendidikan dan Kebudayaan Republik Indonesia Nomor 63 Tahun 2014 Tentang Pendidikan Kepramukaan Sebagai Ekstrakurikuler Wajib http://simpuh.kemenag.co.id. Diakses pada tanggal 1 April 2019

Utomo, J. 2015. "Pelaksanaan Ekstrakuliler Pramuka di SD Negeri IV Wates". Skripsi. Yogyakarta: Universitas Negeri Yogyakarta.

Woro, Sri dan Marzuki. 2016. "Peran Kegiatan Ekstrakurikuler Pramuka dalam Pembentukan Karakter Tanggung Jawab Peserta Didik di SMP Negeri 2 Windusari Magelang". https://journal.uny.ac.id/index.php/joka/. Diakses pada tanggal 9 Juni 2018. 